\title{
Belt, Road and (Legal) Suspenders
}

\author{
Entangled Legalities on the 'New Silk Road'
}

TOMER BROUDE

\subsection{Introduction}

This chapter aims to make three main descriptive and implicitly critical points of varying importance regarding the phenomenon of 'entangled legalities, ${ }^{1}$ using China's 'Belt and Road Initiative' (BRI) as a platform for discussion.

The first point, deceptively the simplest, is that legal entanglement is not necessarily an outcome of chance, anarchy or disorder, but can rather be produced and augmented by centralized (albeit not necessarily structurally hierarchical) political aims and ideas, that create legal and regulatory ripple effects, in ways both intended and unintended. Thus, for example, BRI, also previously known as the 'One Belt, One Road' (OBOR) and more romantically as the 'New Silk Road', is a central controlling idea in the People's Republic of China's (PRC) thirteenth five-year plan (2016-20) and beyond, ${ }^{2}$ clearly guided from above within

Thanks to Yael Berda, Marcia Harpaz, Nico Krisch and Heng Wang for comments on earlier drafts, and to the participants in the May, 2018 workshop on 'Entangled Legalities' at the Graduate Institute Geneva. The cut-off date for factual discussion in this chapter is 15 September 2019, and all websites referred to were accessible then.

${ }^{1}$ As identified in this project's framing piece, see Chapter 1.

2 See Chapter 51, 'The 13th Five-Year Plan for Economic and Social Development of the People's Republic of China' (official translation https://en.ndrc.gov.cn/newsrelease_8232/ 201612/P020191101481868235378.pdf); and National Development and Reform Commission, Ministry of Foreign Affairs and Ministry of Commerce of the People's Republic of China, 'Vision and Actions on Jointly Building Silk Road Economic Belt and 21st-Century Maritime Silk Road' (March 2015), https://en.ndrc.gov.cn/newsrelease_ 8232/201612/P020191101481868235378.pdf. For comprehensive analysis, see J. Chaisse and J. Górski (eds), The Belt and Road Initiative: Law Economics and Politics (Brill Nijhoff, 2018); and H. Wang, 'China's Approach to the Belt and Road Initiative: Scope, Character and Sustainability' (2019) 22(1) Journal of International Economic Law 29-55. 
PRC political hierarchies. ${ }^{3}$ Nevertheless, its local and international legal implications are in many respects non-hierarchical, diffuse and decentralized, touching upon a very broad and diverse range of distinctive, though not entirely discrete, norms, systems and especially actors. The interaction between the presumptively hierarchical and the miscellany of interacting parts, so to speak, produces a high level of legal entanglement. In other words, legal entanglement, or entangled legalities, can be the outcome of strategic thinking and intent, a type of deliberate order of governance, applied to a diversity of actors that serve as nodes or bridges of entanglement between otherwise disparate legal systems. These ideas are expanded on in Section 5.2, using BRI as a case study.

The second point is that, a priori, entangled legalities cannot exist without high degrees of separateness or compartmentalization between norms, systems and actors, even as they constantly interact with each other. This is not merely a trite dialectical observation - that is, just like threads in a ball of string, there must be separate strands of legality for them to become entangled - but a statement related to the structures of legal and law-relevant practice. A global or multi-regional governance project - if that is indeed what it is ${ }^{4}$ - as massive and largely opaque but increasingly familiar as BRI, is obviously overwhelming in its scope and implications to individuals and indeed to organizations (both public and private, governmental and non-governmental). Arguably, most legal practitioners and/or private/public economic operators and government officials in the multitude of relevant jurisdictions do not consider their everyday work to be part of the overall project of BRI or related to it, or at least it's not the primary way in which they understand their work. Many

${ }^{3}$ On BRI/OBOR as a global geopolitical and economic strategy, see U. W. Chohan, 'The Political Economy of OBOR and the Global Economic Center of Gravity', in J. Chaisse and J. Górski (eds), The Belt and Road Initiative: Law Economics and Politics (Brill Nijhoff, 2018), pp. 59-82, at p. 59. A much harder line, that envisions China's strategy for global supremacy, is taken in M. Pillsbury, The Hundred-Year Marathon: China's Secret to Replace America as the Global Superpower (St. Martin's Griffin, 2015), p. 244, mentioning $\mathrm{BRI} / \mathrm{OBOR}$ only as a means to an end.

${ }^{4}$ Many contend that it is, and China does not seem to conceal this; see W. Zhou and M. Esteban, 'Beyond Balancing: China's Approach towards the Belt and Road Initiative' (2018) 27 Journal of Contemporary China 487-501; W. A. Callahan, 'China's "Asia Dream": The Belt Road Initiative and the New Regional Order' (2016) 1 Asian Journal of Comparative Politics 226-43. A fascinating though clearly propagandist exposé of BRI as a global governance project, including rhetoric on 'the construction of a community with a shared future for mankind', can be found in H. Liang and Y. Zhang, The Theoretical System of Belt and Road Initiative (People's Publishing House and Springer Nature, 2019). 
might not even know what BRI actually is, if only because it does not conform to more standardized international economic legal structures and conventions. They are just 'doing their job' within much more limited, object specific, cognitively manageable and often jurisdictionally divided (ratione loci or ratione materiae), a.k.a. 'siloed', strands of an overarching legal entanglement to which they might be largely oblivious in practice. This is demonstrated through a stylized and imagined ethnography (which is nevertheless well grounded in realistic scenarios), undertaken in Section 5.3, the heart of this chapter, in which I trace the different legal practices and local perspectives of particular individual actors, legal and other, ${ }^{5}$ engaging in this era, in different ways, with BRI. These actors are the contact points of entanglement, each of them representing a normative and/or legal system that is entangled with BRI and with other systems. These actors include, for example, an investment protection lawyer at MOFCOM ${ }^{6}$ in Beijing, a public procurement regulator in Greece, an associate or partner at (insert big law firm name) in Kazakhstan, insurgents in Balochistan and judges in national constitutional courts and indeed regional courts such as the Court of Justice of the European Union and the European Court of Human Rights.

Taking note of their separateness, the distinctive and representative existence of these individual narratives should not be taken to imply

5 The focus here is deliberately on individual actors and agents engaged with different levels and dimensions of law; the role of the individual in international legality is increasingly acknowledged, from a variety of perspectives. See, e.g., A. Peters, Beyond Human Rights: The Legal Status of the Individual in International Law (Cambridge University Press, 2016); T. Megiddo, 'Methodological Individualism' (2019) 60 Harvard Journal of International Law 219-80; and T. Broude and I. Levy, 'Outcome Bias and Expertise in Investigations under International Humanitarian Law' (2020) 30(4) European Journal of International Law, 1303-18.

${ }^{6}$ MOFCOM is China's Ministry of Commerce. As international trade and governance scholars Gao and Shaffer have recently put it, 'MOFCOM has a Janus-faced role of looking inward and outward', in the sense that it regulates both domestic and international commercial affairs - see G. Shaffer and H. Gao, 'China's Rise: How it took on the U.S. at the WTO' (2018) 1 University of Illinois Law Review 115-84, at 138. As in trade, the MOFCOM mandate covers both outgoing and incoming foreign investment, including International Investment Agreements; see K. P. Sauvant and V. Z. Chen, 'China's Regulatory Framework for Outward Foreign Direct Investment' (2014) 7 China Economic Journal 141-63; and A. C. Dai, 'The International Investment Agreement Network under the "Belt and Road" Initiative', in J. Chaisse and J. Górski (eds), The Belt and Road Initiative: Law Economics and Politics (Brill Nijhoff, 2018), pp. 220-49, at p. 220. 
disentanglement in any way. Rather, the opposite is true; this separateness establishes a pattern of a set of different systems, approaches and perspectives that coexist with normative entanglement. Put differently, this is not simple, straightforward self-containment or 'fragmentation' of international law. ${ }^{7}$ Rather, to my mind the main contribution of the concept of international or transnational legal entanglement is its emphasis on querying how different legal norms and systems, with heterogeneous yet often shared legal foundations, engage with each other in unanticipated circumstances. Thus, Section 5.4 demonstrates how the seemingly separate worlds of law and practice can come together, and indeed are already conjoined in an actual case - the Belgrade-Budapest railway project - emphasizing their interdependencies, some of them unexpected and counterintuitive, but in any case, deeply legally entangled.

The third point, discussed in the concluding Section 5.5, builds on the first two, and is well demonstrated by BRI, namely that entangled legalities may be strongly and positively associated with the gradual, messy and piecemeal process of empire-building, or at least empirebidding. The combination of top-down and bottom-up forces of legal entanglement create flexibilities and benefits for hegemonic contenders, such as in the present case, China, that well acknowledge their own political constraints.

\subsection{Between Centralized Goals and Localized Effects: Entanglement, from above}

Perhaps counterintuitively, entangled legalities are not necessarily (or at all) a chance or accidental occurrence, disrupting an otherwise settled and logically well-organized legal order. Entangled legalities clearly defy

7 The fragmentation of international law has been a central feature in both the practice and theorization of international law since the rise of distinct regimes and institutions in the 1990s, exacerbating the decentralized and anarchic nature of international law (see, e.g., M. Koskenniemi and P. Leino, 'Fragmentation of International Law? Postmodern Anxieties' (2002) 15 Leiden Journal of International Law 553-79; Report of the Study Group of the International Law Commission, 'Fragmentation of International Law: Difficulties Arising from the Diversification and Expansion of International Law' (13 April 2006) UN Doc A/CN.4/L.682, as corrected (11 August 2006) UN Doc A/CN.4/ L.682/Corr.1 (finalized by Martti Koskenniemi). It remains a fixture of international legal debate to this day (e.g. T. Megiddo, 'Beyond Fragmentation: On International Law's Integrationist Forces' (2019) 44 Yale Journal of International Law 115-48). 
the neat analytics of the Kelsenian idea of a 'hierarchical structure' or stufenbau ${ }^{8}$ - in the absence of any clear pyramid between the enmeshed norms involved - or any pretence of distinguishing, in a Hohfeldian sense, between rights, liberties, powers and immunities. ${ }^{9}$ Entangled legalities plainly lie in the theoretical and practical realms of legal pluralism, ${ }^{10}$ characterized as 'complex intertwined networks'. ${ }^{11}$ Add to these the substantively contested but formally accepted public and private law distinction, ${ }^{12}$ and further dimensions of entanglement emerge. It is not, however, always that difficult to 'fix the own point of departure' of entanglement, ${ }^{13}$ if one accepts that entangled legalities can actually be a preference, 'from above'. They may express a preference for legal plurality that serves centralized and powerful interests and ideas - even hegemonic aspirations - better and more flexibly than a clearly defined hierarchy. This is to say that entanglement can be an established mode of legal and regulatory governance, at both macro (centralized) and micro (localized) levels. Regarding public (and private) international law it is not merely a phenomenon of the famous international 'anarchical society $^{14}$ - it is not necessarily a form of anarchy at all, even if it defies the suffix '-archy'. Thus, in terms of 'pathways' to its emergence, there is a type of legal entanglement that is inevitably a combination of mutual benefit, appeal and coercion, ${ }^{15}$ or alternatively, imperfectly close to

${ }^{8}$ H. Kelsen, 'The Concept of the Legal Order' (1982) 27 The American Journal of Jurisprudence 64-84.

9 W. N. Hohfeld, 'Fundamental Legal Conceptions as Applied in Judicial Reasoning' (1917) 26 The Yale Law Journal 710-70.

${ }^{10}$ See Section 1.1 in Chapter 1.

11 T. Duve, 'Entanglements in Legal History: Introductory Remarks', in T. Duve (ed.), Entanglements in Legal History: Conceptual Approaches (Max Planck Institute for Legal History, 2014), pp. 3-25, at p. 8.

12 M. Rosenfeld, 'Rethinking the Boundaries between Public Law and Private Law for the Twenty First Century: An Introduction' (2013) 11 International Journal of Constitutional Law 125-28 and subsequent contributions in the same issue of the journal: A. Supiot, 'The Public-Private Relation in the Context of Today's Refeudalization' (2013) 11 International Journal of Constitutional Law 129-45; P. Goodrich, 'The Political Theology of Private Law' (2013) 11 International Journal of Constitutional Law 146-61; and J. Resnik, 'Globalization(s), Privatization(s), Constitutionalization, and Statization: Icons and Experiences of Sovereignty in the 21st Century' (2013) 11 International Journal of Constitutional Law 162-99.

13 Duve, 'Entanglements in Legal History', p. 8.

${ }^{14}$ H. Bull, The Anarchical Society: A Study of Order in World Politics (Macmillan, 1977).

15 Krisch identifies these three 'pathways' to entanglement, see Section 1.4.2 in Chapter 1. 
coercion, the outcome of a fourth pathway - through implicit dominance or disguised hegemony.

In other words, whether by default or by design, a central actor, which has the authority and perhaps even the real power to create a structured, hierarchical legal system, may refrain from doing so or even prefer not to if this conduct better serves its goals, and if the costs of hierarchical regulation outweigh its benefits. Moreover, grand ideas can be both centralized as guiding elements - telos or telo $i$ - and in this respect can be very effective in creating localized effects through legal entanglement. The BRI is, arguably, a case in point. I return to this, in brief, in Section 5.5.

But what is BRI or the 'New Silk Road', actually? BRI defies definition, yet cannot be ignored. At its rawest, it can be understood straightforwardly as an ambitious programme of infrastructure project finance within China (primarily in the less developed western provinces) ${ }^{16}$ and in dozens of other countries, spreading to the south and mainly outward to the west of China, all to the tune of US\$1 trillion to be invested over twenty years. BRI, which has been often been analogized to the postWorld War II 'Marshall Plan', ${ }^{17}$ can transform the living conditions of hundreds of millions throughout the nether lands of South and Central Asia, reaching into Africa and, more discreetly, into Europe.

Indeed, Europe seems to be very much a crucial economic objective of BRI, presenting a 'pivot to Europe' in response to the Obama administration's now all but forgotten 'Pivot to Asia' which included US leadership in negotiations over the Trans-Pacific Partnership (TPP), ${ }^{18}$ a policy

16 See A. Chatzky and J. McBride, 'China's Massive Belt and Road Initiative', Council on Foreign Relations Backgrounder (21 May 2019), www.cfr.org/backgrounder/chinas-mas sive-belt-and-road-initiative.

${ }^{17}$ Quite recently: 'Will China's Belt and Road Initiative Outdo the Marshall Plan?', The Economist (8 March 2018), www.economist.com/finance-and-economics/2018/03/08/ will-chinas-belt-and-road-initiative-outdo-the-marshall-plan.

18 The TPP was envisioned as a 'mega-regional' trade and investment agreement encompassing most of the economies of the Pacific Rim. One of President Trump's first decisions upon entering office was to withdraw from the TPP, with significant regional implications (see S. Narine, 'US Domestic Politics and America's Withdrawal from the Trans-Pacific Partnership: Implications for Southeast Asia' (2018) 40 Contemporary Southeast Asia 50-76). All other parties to the negotiations continued to discuss a revised regional trade agreement without the USA, the Comprehensive and Progressive Agreement for Trans-Pacific Partnership, which entered into force for the first six ratifying states in December 2018; for comparison, see H. Wang, 'The Future of Deep Trade Agreements: The Convergence of TPP (and CPTPP) and CETA)?' (2019) 53 Journal of World Trade 317-42. 
obliterated by President Trump but not considered a great success even beforehand. ${ }^{19}$ Chinese investments in European ports and rail systems are transforming market access and distribution in the EU much more positively than the legal conundrums of Brexit will. ${ }^{20}$ Reportedly, China now controls - in current terms - one-tenth of all European port capacity, with gateways in Piraeus, Zeebrugge and elsewhere. ${ }^{21}$ This can only be expected to expand, as China invests in rail infrastructures through the Balkans to central Europe. ${ }^{22}$ Thus, BRI is not only important in simple economic terms. The historical Silk Road had two sides; from a Eurocentric perspective, it was a road to China, from a Chinese perspective it was a road to Europe. BRI is more of the latter than the former. Europeans have only recently started to grasp this, ${ }^{23}$ as more states in the EU sign on to the programme (e.g. Greece, Hungary, Italy) - literally through 'non-binding' BRI Memoranda; ${ }^{24}$ attend BRI diplomatic forums; and grant Chinese firms infrastructure projects and accept their loans. This has created an intra-EU tension between member states and the EU Commission, which is explicitly more reserved regarding China and $\mathrm{BRI},{ }^{25}$ due to concerns about foreign investment approval and

${ }^{19}$ M. J. Green, 'The Legacy of Obama's 'Pivot' to Asia', Foreign Policy (3 September 2016), https://foreignpolicy.com/2016/09/03/the-legacy-of-obamas-pivot-to-asia/.

${ }^{20}$ Indeed, some see the possible strengthening of the United Kingdom's bilateral economic relations with China as a remedy to problems arising from Brexit, while others see it as a threat to the UK's sovereignty; see K. Brown, 'How Brexit Britain Can Gain from China's Belt and Road', This Week in Asia (12 May 2017), www.scmp.com/week-asia/opinion/ article/2094166/what-brexit-britain-has-gain-chinas-belt-and-road; and M. Auslin, 'Brexit Britain Is Eager for a Sweet Deal with Beijing: But at What Price?', The Spectator (4 August 2018), www.spectator.co.uk/2018/08/making-china-great-again/. As of the time of this writing, there is no United Kingdom-China trade arrangement outside of the WTO.

${ }^{21}$ See K. Johnson, 'Why Is China Buying up Europe’s Ports?', Foreign Policy (2 February 2018).

22 'Serbia Starts Construction of Chinese-Funded Railway to Budapest', Reuters (28 November 2017), www.reuters.com/article/serbia-china-railway/serbia-starts-con struction-of-chinese-funded-railway-to-budapest-idUSL8N1NY4RR.

23 AFP, 'Europe Casts a Wary Eye on China's Silk Road Plans', Straits Times (7 January 2018), www.straitstimes.com/world/europe/europe-casts-a-wary-eye-on-chinas-silkroad-plans.

24 See Memorandum of Understanding between the Government of the Republic of Italy and the Government of the People's Republic of China on Cooperation within the Framework of the Silk Road Economic Belt and the 21st Century Maritime Silk Road Initiative (March 2019), www.governo.it/sites/governo.it/files/Memorandum_Italia-Cina_EN.pdf.

25 See European Commission and High Representative of the Union for Foreign Affairs and Security Policy, 'Joint Communication to the European Parliament, the European Council and the Council, EU-China - A Strategic Outlook' (12 March 2019) JOIN 
debt-entrapment, ${ }^{26}$ and prompted the EU Commission to develop closer economic relations with Japan, including a very recent bilateral agreement on infrastructure connectivity, depicted as a counter to BRI. ${ }^{27}$

Moreover, it would be naïve to think that BRI is not indeed also a governance project, potentially the greatest geopolitical transformation since the end of the first Cold War, aiming to create a Eurasian economic and political space under Chinese dominance. It brings to mind George Kennan's 'Long Telegram' regarding Soviet influence after World War II, in that it 'involves questions so intricate, so delicate, so strange to our form of thought, and so important to analysis of our international environment that I cannot compress answers into single brief message without yielding to what I feel would be a dangerous degree of oversimplification'. ${ }^{28}$ The EU Commission EU-China: Strategic Outlook document from 2019, ${ }^{29}$ is of course a public document and hence much more cautious in its drafting; notably, however, it does not mention BRI by any of its names, while the word security appears, in a variety of contexts, much more than the words trade or investment. In other words, the EU has become acutely aware of the geopolitical/economic gauntlet that China has thrown down through BRI.

But again, what is BRI, in legal governance terms? It has been noted that locating the 'formal legal sources, either domestic or international' of

(2019) 5 final, https://ec.europa.eu/commission/sites/beta-political/files/communicationeu-china-a-strategic-outlook.pdf. Belgian/EU politician and EU Parliament Brexit coordinator Guy Verhofstadt has said that Italy's endorsement of BRI is 'antithetical' to the interests of the EU and its member states (see G. Verhofstadt, 'Europe Must Unite on China', ING THINK Outside (29 March 2019), https://think.ing.com/opinions/guy-ver hofstadt-europe-must-unite-on-china/.

26 'Debt trap diplomacy' concerns - the idea that high financial indebtedness to China will cause political dependence - has also been raised in Asia, in particular following the leasing of the Hambantota Port to a Chinese corporation for ninety-nine years, following loan non-performance; see T. H. Shih, 'China Risks Imperial Image With Belt and Road Initiative', Asia Sentinel (8 October 2019), www.asiasentinel.com/econ-business/chinaimperial-image-belt-and-road-initiative/.

27 See European Commission, 'EU Charts New Ground in Global Connectivity - Looks to Boost Strategic Ties with Asia', Press Release IP/19/5851 (26 September 2019), https:// europa.eu/rapid/press-release_IP-19-5851_en.htm.

${ }^{28}$ George Kennan (22 February 1946), https://digitalarchive.wilsoncenter.org/document/ 116178.pdf.

29 See European Commission and High Representative of the Union for Foreign Affairs and Security Policy, EU-China: A Strategic Outlook (12 March 2019), JOIN (2019) 5, https:// ec.europa.eu/info/sites/default/files/communication-eu-china-a-strategic-outlook.pdf. 
BRI is a difficult task. ${ }^{30}$ Heng Wang has called the Chinese approach to BRI 'less institutional', presumably in comparison with Western approaches that have relied on institutions in the architecture of international law and regimes. Within this Chinese approach he notes two layers or categories of non-domestic law relevant to BRI: first, 'BRIspecific' documents, such as the increasing number of non-binding or binding Memoranda of Understanding (MOUs) between China and states and international organizations; ${ }^{31}$ and second, 'BRI-related' rules that can apply to BRI economic activity, such as World Trade Organization (WTO) law, regional trade agreements and international investment agreements. ${ }^{32}$ To these one might add a variety of international legal rules and norms that are also BRI-related, such as human rights instruments, and environmental, maritime and other standards and private law. Seeking further for historical and institutional analogies, one can clutch on to the Asian Infrastructure Investment Bank, established by China supposedly as an alternative to longstanding multilateral development banks, a competitor to the World Bank Group and an essential political and economic instrument for BRI. ${ }^{33}$ One can also look to the Silk Road Fund, a multi-million dollar investment fund, wholly controlled by China. ${ }^{34}$ But as China scholar Maria Adele Carrai has written, these financial branches do not provide BRI with a rigid legal structure. ${ }^{35}$ BRI does not have a 'membership', an 'institution', a 'decision-making' process. It does not fit easily into any boxes of conventional international legal order. This does not mean, however, that it does not have many significant implications for law in its spheres of influence, creating entangled legalities at many levels, down to the most localized.

${ }^{30}$ L. Zeng, 'Conceptual Analysis of China's Belt and Road Initiative: A Road towards a Regional Community of Common Destiny' (2016) 15 Chinese Journal of International Law 517-41, at 539 .

31 Such as the 2017 MOU between China's National Development and Reform Commission (NDRC) and the United Nations Economic Commission for Europe (UNECE) (UNECENDRC MOU), www.unece.org/fileadmin/DAM/MoU_between_UNECE_the_NDRC_ in_China_2017-05-14.pdf; and AFP, 'Europe Casts a Wary Eye on China's Silk Road Plans'.

32 Wang, 'China's Approach to the Belt and Road Initiative', section II.

${ }^{33}$ M. Callaghan and P. Hubbard, 'The Asian Infrastructure Investment Bank: Multilateralism on the Silk Road' (2016) 9 China Economic Journal 116-39.

${ }^{34}$ See www.silkroadfund.com.cn/.

${ }^{35}$ M. A. Carrai, 'It Is Not the End of History: The Financing Institutions of the Belt and Road Initiative and the Bretton Woods System' (2017) 14 Transnational Dispute Management 1-14, at 2-3. 
To be sure, the present section of this chapter does not aspire to provide a comprehensive descriptive analysis of BRI. Indeed, the nature of the beast, as already stylized above, as well as the current flux in international 'geoeconomics', ${ }^{36}$ would seem to preclude this. ${ }^{37}$ Rather, the point to be made is that while BRI evidently constitutes a complex system of entangled legalities, it would appear to have been deliberately conceived as such, 'top down', by its initiator, not by chance or oversight, and in lieu of attempting to establish a less entangled, more structured (if not hierarchical) form of governance.

One possible point of departure towards understanding this and its implications for entangled legalities, is the top-down definition of the BRI goals, as set out quite innocuously in Chapter 51 of the PRC's thirteenth five-year plan, ${ }^{38}$ which reads as follows:

We will uphold amity, sincerity, mutual benefit, and inclusiveness as well as the principle of joint discussion, common development, and shared growth as we look to undertake practical and mutually-beneficial cooperation in multiple sectors with countries and regions involved in the Belt and Road Initiative, with the aim of developing a new picture of allaround opening up in which China is opened to the world through eastward and westward links and across land and sea [emphases added]. ${ }^{39}$

Compare to this unexpected source, Article 2 of the 1957 Treaty of Rome establishing the European Economic Community:

The Community shall have as its task, by establishing a common market and progressively approximating the economic policies of Member States, to promote throughout the Community a harmonious development of economic activities, continuous and balanced expansion, an increase in stability, an accelerated raising of the standard of living and closer relations between the States belonging to it [emphases added]. ${ }^{40}$

These passages are fascinating, when read side by side, in both their similarities and their differences. The similarities of mutual benefit,

${ }^{36}$ See A. Roberts, H. C. Moraes and V. Ferguson, 'The Geoeconomic World Order', Lawfare (19 November 2018), www.lawfareblog.com/geoeconomic-world-order, arguing that at this time 'We appear to be entering into a new geoeconomic world order, characterized by great power rivalry between the United States and China and the clear use of economic tools to achieve strategic goals'.

37 The sources in $n$. 2 provide the most comprehensive surveys to date, especially Wang.

38 Ibid.

39 See n. 2.

40 See Art. 2 of EEC, 'Treaty of Rome: Treaty Establishing the European Economic Community’ (25 March 1957) 298 U.N.T.S. 3, 4 Eur. Y.B. 412. 
economic development amity and harmony are clear (although also worthy of deeper theoretical analysis in other contexts). The differences relate to the conceptual mindset of governance. 'The Community' contrasts with 'We', 'task' may be opposed to 'aim'. China's five-year plan sets out goals and aspirations for BRI, leaving open the institutional technology for their achievement, while placing China firmly as primus inter pares in a decentralized project. Elsewhere one can find that BRI has a driving concept of a 'community of common destiny', ${ }^{41}$ but the terms in which it is couched only enhance the difference in institutional (or non-institutional) design - China at the centre of a decentralized system (oxymoron intended). In contrast, the corollary in the Treaty of Rome sought to establish an orderly structure of institutional governance, which will have as its task the achievement of its common goals.

We know how dramatic the Treaty of Rome has been for the peoples of Europe over the last six decades, for its governance and for its legalities, which are often entangled but nevertheless structured upon formal principles such as direct effect, supremacy and subsidiarity. We do not know how dramatic the vision of BRI, posed in its own terms, will be over the next decades. But it can be said that it is a politically centralized vision that can have manifold unintended consequences in many established legal systems - in any state or territory that BRI relates to, directly or indirectly, in any international legal system that it relates to, and indeed in any issue area of regulation or legal domain. Perhaps the key phrase in the paragraph quoted from the five-year plan is 'a new picture'. Let us try to hypothesize what this picture could be - indeed, already is - for a variety of entangled legal actors.

\subsection{Between Separateness and Entanglement: Vignettes of Entangled Legal Practice on the New Silk Road}

A comprehensive study of the different legal practices and local perspectives of particular individual actors, legal and otherwise, with BRI, is well beyond the scope of this chapter. Nevertheless, I wish to demonstrate that these actors are the very contact points of entanglement, each of them representing a normative and/or legal system that is entangled with BRI and with other systems. The following are constructed vignettes of professionals and other agents interacting with BRI and other related

${ }^{41}$ D. Zhang, 'The Concept of "Community of Common Destiny" in China's Diplomacy: Meaning, Motives and Implications', Asia and the Pacific Policy Studies (16 April 2018). 
legal systems in recent history, from variegated legal and geographical perspectives. The reader can consider this as a narrative or as an imagined or hypothetical ethnography, ${ }^{42}$ but the section does not aspire to methodological insight, rather aiming at illustrating one end of the spectrum of legal entanglement, namely, the relative separateness of legal actors, actions and environments and their interconnections. The names, characters and incidents portrayed can be thought of as fiction, but they are all based on or derived from real situations. Thankfully, there are social scientists and legal scholars conducting actual field research in this area. The contribution here is aimed towards the theory of entangled legalities, not to legal sociology or anthropology or to the empirical study of BRI, at least not directly.

The main point to be made here is that entangled legalities exist on a regular basis, first and foremost because of separateness and compartmentalization derived from structures of legal and law-relevant practice, as well as overarching cognitive limits, that constrain these actors to a focus on their particular environments, backgrounds and objectives. In Section 5.4 I show, through a more detailed real-life example, how this separateness is only part of the story of legal entanglement, as the distinct fields of legal practice inevitably, though sometimes unexpectedly, have points of contact and interdependence.

Let us start where it all begins, in China itself, with an initial ethnographical vignette. $A$ is a very senior lawyer at the investment law division of MOFCOM, the PRC's Ministry of Commerce. ${ }^{43} A$, in his late thirties, works in Beijing, which is no less than the centre of the real-world universe for him (forget about Manhattan or Berlin, unless you are thinking of Leonard Cohen). Born in a prefecture-level city in Hubei province in central China, he has been predominantly trained and groomed in the PRC, from a very young age, for public service, through its system of

42 Ethnography is a (not uncontroversial) anthropological/sociological qualitative methodology of describing people or cultures through observation; it has become accepted also in socio-legal studies (see, e.g., J. Starr and M. Goodale (eds), Practicing Ethnography in Law: New Dialogues, Enduring Methods (Palgrave Macmillan, 2002)) entailing interviews, field research and other qualitative social science methods. An excellent example of ethnographical research in the field of international economic law is G. A. Sarfaty, Values in Translation: Human Rights and the Culture of the World Bank (Stanford University Press, 2012). The vignettes in this section are not based on such systematic research, so they cannot claim to be a true ethnography, and don't wish to be, hence the qualifiers 'imagined' or 'hypothetical'.

43 See references in n. 6 . 
'meritocracy'. ${ }^{44} \mathrm{He}$ is, however, distinctly a 'man of the world'. He holds an LLM degree from a leading law school in the USA, speaks excellent English, and has travelled - in his professional capacity, of course, primarily as an advisor to trade and investment agreement negotiations, perish the thought of corruption - several times to Brussels, Singapore, Kuala Lumpur, Johannesburg, Dubai and Canberra, and has previously worked at a junior level in the Chinese delegation in Geneva. Despite his worldliness, his sights are always set on promotion within the Chinese system. He cautiously hopes to hold high office in the Party and government someday. ${ }^{45}$ To him, BRI is very significant. It will project and extend China's economic and political power and prowess to the world, and $A$ is both confident and proud that he is part of this project, in particular because it will, on balance, bring wealth, welfare and Chinese values to other cultures. ${ }^{46}$ Law is an important instrument to this end, utilizing formats developed by Western powers (such as International Investment Agreements (IIAs), which he negotiates) ${ }^{47}$ that are now fundamental for facilitating and establishing China's trade and investment policies, which can promote BRI as a significant global public good. ${ }^{48}$ Entangled legality is de rigueur, it comes naturally, so long as the overarching goals are promoted and ideally achieved. $A$ is not concerned at all with the formal problem posed by parallel or even contradictory legal systems, such as international investment agreements and commercial obligations, ${ }^{49}$ so long as they serve the greater purposes of BRI.

${ }^{44}$ For a survey on competing views regarding Chinese meritocracy, and a comparison with promotion systems in Western democracies (at the ministerial level), see D. S. Lee and P. J. Schuler, "Testing the "China Model" of Meritocratic Promotions: Do Democracies Reward Less Competent Ministers than Autocracies?' (2020) 53 Comparative Political Studies 531-66.

45 The Communist Party plays a crucial role in Chinese governance, and according to some analysis, over the last few years, administrative power is shifting in the direction of the Party; see L. L. P. Gore, 'The Communist Party-Dominated Governance Model of China: Legitimacy, Accountability, and Meritocracy' (2019) 51 Polity 161-94.

${ }^{46}$ In line with Part 16 of the five-year plan (see n. 2), which addresses socialist values and ethics as well as Chinese cultural heritage.

47 On China's BRI IIA policy, see Dai, 'The International Investment Agreement Network under the "Belt and Road" Initiative'; and Sauvant and Chen, 'China's Regulatory Framework for Outward Foreign Direct Investment'.

48 Similarly, see C. He, 'The Belt and Road Initiative as Global Public Good: Implications for International Law', in W. Shan, K. Nuotio and K. Zhang (eds), Normative Readings of the Belt and Road Initiative: Road to New Paradigms (Springer, 2018), pp. 85-104.

49 As an example, China has at least two co-existing agreements with South Korea, which include investment protection provisions - a Bilateral Investment Agreement from 2007 and a Trade Agreement from 2012. 
For $A$, 'law' is technically public international law, that needs to be upheld as an overarching order that serves China's interests in general and BRI in particular; but in practice much of it is commercial law. This need not be enforced through traditional Western dispute settlement systems, but through combinations of legal argumentation and diplomacy, and alternative dispute resolution procedures, such as mediation. ${ }^{50}$

Moving on to another entangled and entangling actor at the European portal representing the other end of BRI, $B$ is a mid-level legal counsel in the Greek Ministry of Infrastructure, Transport and Networks in the Athens suburb of Cholargos. At the age of thirty-two, B's worldview is inevitably coloured by the financial and government debt crises of the 2000s that began when she was a law student at the Kapodistrian University of Athens, and the scepticism that it has brought in Greece towards international institutions, both at the $\mathrm{EU}_{\text {level }} \mathrm{l}^{51}$ and beyond. $B$ aspires to attain an internationally recognized graduate law degree, perhaps in the UK (though this is becoming less attractive because of Brexit, making the Netherlands her new first choice), but she first needs to establish herself economically and in her professional career, and perhaps start a family. $B$ is a formalist, she follows the book, even when the book is blurred. But she also patriotically understands her state's strengths and weaknesses, and that an opportunity for foreign investment and increased employment should not be passed up. In her eyes, austerity, imposed by international neoliberal forces, pales in the face of the riches offered by a powerful and trustworthy economic good faith partner from China. The Chinese state-operated enterprises that offer lucrative terms for infrastructure projects that place Greece at a crucial juncture between China and the rest of Europe are a breath of fresh air. Yes, the Chinese can be

${ }^{50}$ China has been involved in only a handful of disputes under its IIAs. There is a trend towards constructing and viewing BRI projects and potential disputes related to them as private, commercial law issues, and within that framing to encourage resolution through mediation; see, e.g., the MOU reportedly signed by the Singapore International Mediation Centre and the China Council for the Promotion of International Trade in January 2019, setting up a BRI-focused panel of mediators (T. D. Wei, 'Singapore, China to Set Up Mediators' Panel for Belt and Road Projects', Straits Times (25 January 2019), www .straitstimes.com/asia/east-asia/singapore-china-to-set-up-mediators-panel-for-belt-androad-projects).

${ }^{51}$ Greece was traditionally a Europeanist state, but public opinion towards the EU and its major member states has declined, although not to the level of 'Grexit'; see B. Clements, K. Nanou and S. Verney, “We No Longer Love You, But We Don't Want to Leave You”: The Eurozone Crisis and Popular Euroscepticism in Greece' (2014) 36 Journal of European Integration 247-65. 
difficult to deal with, but they don't have the arrogance of the Western Europeans or Americans. ${ }^{52}$ They know what civil law means and are willing to negotiate flexibly and pragmatically. $B$ is not really sure what BRI is - she's heard of it, after all she reads the Greek economic press and The Economist from time to time. Over the last few years, however, she has been much more focused on settling the terms of the corporate franchise of a shipping container terminal in the port of Piraeus, and the sale of a majority share in the port authority, with a huge Chinese state-owned shipping company. As time goes by, she takes pride in her small professional contribution to the major increase in shipping container traffic through Piraeus (about ten times the 2008 volume), ${ }^{53}$ as well as the increase in the number of Chinese tourists visiting Greece, all of which have helped the Greek economy. She was delighted when, in August 2018, the Tsipras government signed a BRI MOU with China, and is pleased that the current government is continuing to expand the relationship, while cognizant of US and EU concerns. ${ }^{54}$

For $B$, law is mainly Greek administrative and corporate law, in the shadow of EU law; $A$ 's world of law is entirely foreign to her.

In-between $A$ and $B, C$ is a partner in the Almaty office of $X, Y$ and $Z$ LLP, a global 'big law' firm. He is only aged twenty-eight, actually born on the day that Kazakhstan declared sovereignty on its territory just before the dissolution of the Soviet Union. He is considered something of a maverick in the Kazakh energy and infrastructure law scene. Fluent in Kazakh, Russian and English, his legal education is exclusively from law schools in Kazakhstan. He is a deal-maker, building on his excellent family connections. His legal specialty is project finance, and he sees BRI as the future - breaking away from Russia, disengaging from the USA (with which he has become personally disillusioned), China is the way forward to Kazakhstan's prosperity and international recognition. ${ }^{55}$

52 According to public opinion polls (2017), between 50 and 60 per cent of the Greek population considers China favourably; see P. Le Corre, 'China's Rise as a Geoeconomic Influencer: Four European Case Studies', Carnegie Endowment for International Peace Working Paper (2018), p. 20, https://carnegieendowment.org/files/WP_LeCorre_China_ Final_Web.pdf.

53 For more details of COSCO's Piraeus deals, see ibid. at 15.

${ }^{54}$ See S. Lau, 'Amid Headwinds, Greece Gives Cosco Green Light for Partial Piraeus Port Upgrade', South China Morning Post (11 October 2019), www.scmp.com/news/china/diplo macy/article/3032618/amid-headwinds-greece-gives-cosco-green-light-partial-piraeus.

55 See N. Kassenova, 'China's Silk Road and Kazakhstan's Bright Path: Linking Dreams of Prosperity' (2017) 24 Asia Policy 110-16. 
He has worked with US and EU companies on energy projects, but prefers to work with China - far less red-tape, no social and environmental risk assessments through the Equator Principles or Global Compact, ${ }^{56}$ no EU regulations. This is not to say that he is not concerned with these issues, but they can be addressed through Kazakhstan's laws and regulations. He is particularly proud of his involvement with the massive Khorgos 'Dry Port' project, with its potential for regional transformation. ${ }^{57}$

To $C$, law is a somewhat blurry (if not shady) area of Kazakhstani business and corporate law, ${ }^{58}$ transnational financial law and energy law. From the perspective of legal practice, his work is quite similar to that of $B$, but the legal environment is very, very different. As an ambitious young commercial lawyer, he is driven not only by his clients' interests but also by his own - knowing that he and his partners stand to gain a lot from the Chinese presence in Kazakhstan. ${ }^{59}$ He considers himself no less a businessman than a lawyer, and is contemplating entering politics. $\mathrm{He}$ is happy to take Chinese dictates and stay within the bounds of Kazakh legality, so long as the project gets done.

$D$ is a Baloch nationalist and insurgent separatist in Balochistan, the most destitute province in Pakistan, despite being extremely rich in natural gas and minerals - and hence, of great interest to the PRC. Balochistan is also a key building block in BRI, in the form of the 'China-Pakistan Economic Corridor', in which reportedly some US $\$ 60$ billion have been invested or pledged by China, not least in the port of Gwadar on the Arabian Sea, now wholly run by a Chinese corporation,

${ }^{56}$ See http://equator-principles.com/ and www.unglobalcompact.org/ respectively.

57 A. Higgins, 'China's Ambitious New "Port": Landlocked Kazakhstan', New York Times (1 January 2018), www.nytimes.com/2018/01/01/world/asia/china-kazakhstan-silk-road .html; and H. Ruehl, 'The Khorgos Hype on the Belt and Road', The Diplomat (27 September 2019), https://thediplomat.com/2019/09/the-khorgos-hype-on-the-beltand-road/.

${ }^{58}$ Kazakhstan is highly ranked in the World Bank's 'Ease of Doing Business' index (see https://data.worldbank.org/indicator/IC.BUS.EASE.XQ), but its business and corporate law is a patchwork of different legal foundations and practices, itself a legal entanglement; see F. Karagussov, 'Development of Company Law in Kazakhstan: Main Issues and Trends' (2016) 24 Juridica International 84-95; and Baker and McKenzie, 'Doing Business in Kazakhstan 2019' (2019), www.bakermckenzie.com/-/media/files/insight/ guides/2019/doing-business-in-kazakhstan-2019.pdf?la=en.

59 Consider T. Yu, 'China's "One Belt, One Road Initiative”: What's in It for Law Firms and Lawyers?' (2017) 5 The Chinese Journal of Comparative Law 1-21. The article deals primarily with gains to lawyers in China, but clearly the same question is asked by lawyers around the world. 
with a lease until 2059. At twenty-four, he was extremely disappointed with the 2018 surrender of the leadership of the Baloch Liberation Army (BLA), which seems to him connected to China's increased involvement in the region. ${ }^{60} \mathrm{He}$ is very concerned that Chinese control in his homeland will benefit elites and not trickle down to his people. Weighing his steps carefully, he is not excluding the possibility of joining militant factions and insurgents that advocate taking armed action against the Chinese presence and have even attacked Chinese engineers under the name of the BLA, if only to gain more political traction, even independence, by raising political risk to BRI operations. ${ }^{61}$

For $D$, law, in general, is not very relevant. There is tribal law, there are social norms, but he is not concerned with Pakistani law or with contracts beyond a handshake (that is to say, legality can be entangled with an absence of legality too). $A$ 's, $B$ 's and $C$ 's worlds of legality are as distant from him as are their air-conditioned offices.

Even more distant, occupying her own tempered chambers, $E$ is a western European Judge in the European Court of Human Rights. Trained in the best law schools of Europe, a well-respected professor of law in her country and with several honorary doctorates around the world, for her, Strasbourg is no less than the centre of the normative universe (forget about Geneva, Washington, DC or Karlsruhe, let alone San Jose or Beijing), and the European Convention for the Protection of Human Rights and Fundamental Freedoms is her moral compass. It is of course the law, and even more so, it is a constitution. Yes, it can get messy sometimes with the overburdened caseload, and the unclear effectiveness and the constitutional orders of the Council of Europe members, such as Georgia and Azerbaijan. These are BRI states, but now also Greece, Italy, Hungary, Serbia and fourteen other Central and Eastern European states are. BRI is not remotely on her judicial radar, though if something relevant comes up in the

${ }^{60}$ F. Bokhari and K. Stacey, 'China Woos Pakistan Militants to Secure Belt and Road Projects', Financial Times (19 February 2018), www.ft.com/content/063ce350-109911e8-8cb6-b9ccc4c4dbbb.

${ }^{61}$ See D. R. Chaudhury, 'Baloch Liberation Army Attacks Chinese Assets for 3rd Time Since Aug 2018', Economic Times (1 April 2019), https://economictimes.indiatimes.com/ news/defence/baloch-liberation-army-attacks-chinese-assets-for-3rd-time-since-aug2018/articleshow/68664144.cms?from=mdr; and M. A. Notezai, 'Will Balochistan Blow up China's Belt and Road?', Foreign Policy (30 May 2019), https://foreignpolicy.com/ 2019/05/30/will-balochistan-blow-up-chinas-belt-and-road/. 
Caucasus, or anywhere in Europe for that matter, the European Convention and Court will surely kick in.

For E, law is Western, European human rights law, and her legal practice, originally one of scholarship and court-watching, is now firmly the practice of judging.

The list, this cast of characters, can easily go on, but the point should be clear. Each and every one of these legal actors is a constitutive part of BRI, even if they are barely aware of it. They seem to occupy separate universes in which each of their representative narratives does not imply disentanglement, but rather separateness, a separateness that is both necessary for entanglement and coexists with it. They occupy legal silos across national and substantive lines. They are entangled without really knowing it, as they are cognitively limited and object oriented and, above all, practice focused. In Section 5.4 I briefly relate one recent, actual case in which both the separateness and connectedness dimensions of entanglement have been brought to bear.

\subsection{Between Entanglement and Interdependence: Bringing Separate Strands Together}

In light of the extreme plurality of law and viewpoints of practice entangled legalities along the New Silk Road - as described only indicatively in Section 5.3, many questions may arise regarding their interdependence, especially as I have so far emphasized their separateness. For example, how might Chinese officials like $A$ link their efforts and rules with the legalities found in the places where they are doing business and seeking influence, when they come into contact with people like $B$ and $C$ ? How would the last two and their corollaries along the BRI navigate potential tensions between Chinese expectations and their own laws and norms? How should Chinese actors engage with normative sensibilities they may risk offending, such as those of $E$ - and also of $D$ ? To be sure, these questions are worthy of real rather than hypothetical research, whether through doctrinal legal analysis or through political, sociological and anthropological field research. Instead, within the bounds of this chapter, we can look at a brief case study, to appreciate the interdependence of separate entangled strands of legality in action. The following is a brief descriptive analysis of such a case, based on mainly secondary sources.

The case relates to the ongoing project for the modernization of the train line between Belgrade and Budapest, the capitals of Serbia and 
Hungary respectively, and the entanglement of BRI project-related law with EU law. The project, which will include high-speed trains, fits in with the broader vision of modernized train lines from Piraeus/Athens into the heart of central Europe, ${ }^{62}$ and indeed with its engagement strategy with Central and Eastern European countries, which preceded BRI - the so-called ' $16+1$ initiative' informally launched in $2011,{ }^{63}$ now often referred to as ' $17+1$ ', including Greece. Our focus here is on the segment that lies in Hungarian territory and the project's interaction with EU law (Serbia not being an EU member state). Hungary was the first EU member state to sign a BRI MOU with China, in $2015 .{ }^{64}$ In November of the same year, China, Hungary and Serbia signed a US $\$ 1.9$ billion government-to-government (G2G) agreement regarding the BelgradeBudapest line, and the project's main contractor was named - a consortium between the Hungarian State Railways corporation and two Chinese railway companies. This legal relationship - the China-Hungary MOU and the infrastructure construction and financing agreement - constitute one strand in this story of entangled legality. The second strand emerged and entangled with the first once the EU launched a preliminary infringement procedure against Hungary in May 2017, based on concerns that the absence of a competitive tender for the huge contract violated EU competition and procurement law; and that the role of the Hungarian corporation, with only 15 per cent of the deal (and 85 per cent of the project to be funded through twenty-year loans from China) was unclear. Reportedly, the Hungarian government was of the position that since the infrastructure agreement was not within the commercial competence of the EU, it was 'none of Brussels' business' ${ }^{65}$

Even at this early stage of the story - the plot is soon to thicken, though the general setup is the same - one can think of the sources of both separateness and interdependence in this case of entangled legality, at least on a speculative basis. If one is charitable, at least regarding intent

${ }^{62}$ For external analysis, see 'The Potential for Growth through Chinese Infrastructure Investments in Central and South-Eastern Europe along the "Balkan Silk Road", report prepared by Dr Jens Bastian for the European Bank for Reconstruction and Development (July 2017), www.ebrd.com/documents/policy/the-balkan-silk-road.pdf.

63 See T. Matura, 'The Belt and Road Initiative Depicted in Hungary and Slovakia' (2018) 7 (2) Journal of Contemporary East Asia Studies 174-89, section 4.

${ }^{64}$ Ibid., section 5.1.2.

65 J. Spike, 'EC Launches Infringement Proceeding Concerning Budapest-Belgrade Railway Project', Budapest Beacon (16 September 2016), https://budapestbeacon.com/eclaunches-infringement-proceeding-concerning-budapest-belgrade-railway-project/. 
rather than legal capacity, perhaps the Hungarian public and most likely also private lawyers (think of variations of $B$ and $C$ ) involved in the rail infrastructure agreement truly thought that it had nothing to do with $\mathrm{EU}$ law, having been signed between three governments in an area that generally is (so Hungary claims) not within EU competence. Perhaps they just didn't think of it, being so cognitively focused on making the deal on the legal separateness of this kind of agreement. Or, less charitably, maybe they were aware of possible problems, but took the chance in order to make progress with China, and with the hope that the EU would back down for political reasons. Least charitably, they had other incentives that perhaps justified EU scrutiny.

China's lawyers - A's colleagues in a different department of a different ministry and their counterparts in the Chinese corporations - were either oblivious to EU law and/or did not consider the possibility that a governmental party to a G2G agreement would make representations of this nature with any real legal (or political) risk, or perhaps thought that if there were a problem it would be handled as it would have been in China, or were so self-motivated that they chose to ignore all of these issues, or deliberately took this chance in order to signal to the EU their determination to engage with EU member states and corporations directly.

What about the EU Commission lawyers, whom we can to some extent analogize to $E$ ? For them, there is no question that EU law on competition, procurement, corporations and more are applicable, answerable and supreme. To them, the infrastructure agreement is no different than any of the multitude of structurally similar agreements that are subject to EU law. Maybe this one required additional scrutiny due to its size and mainly because of its role in bringing Chinese influence into the heart of Europe. ${ }^{66}$

Apparently, conceding interdependence, Hungary issued a tender for the project later in $2017,{ }^{67}$ and a new one in late 2018 , which was won in April 2019 by a similar Chinese-Hungarian consortium, with a similar financial structure, ${ }^{68}$ but for the fact that the Hungarian partner would be

${ }^{66}$ See J. Kynge, A. Beesley and A. Byrne, 'EU Sets Collision Course with China over "Silk Road" Rail Project', Financial Times (20 February 2017), www.ft.com/content/003bad14f52f-11e6-95ee-f14e55513608.

67 'Hungary to Launch Tender on Budapest-Belgrade Rail Project', RailPro (5 October 2017), www.railwaypro.com/wp/hungary-launch-tender-budapest-belgrade-rail-project/.

68 'Hungarian-Chinese Consortium Wins Budapest-Belgrade Rail Contract', IE - Industry Europe (29 April 2019), https://industryeurope.com/hungarian-chinese-consortiumwins-budapest-belgrade-rail-contract/. 
a company controlled by Lörinc Mészáros, reportedly 'a key ally' of Prime Minister Viktor Orbán, ${ }^{69}$ a strong proponent of the project and of strong relations with China - among his many other well-known political views.

This is not the place to reflect in-depth on either the economic and political undercurrents of this episode, or on its actual outcomes, or on the effectiveness of the different legal actors and legalities involved. What can be said is that in this case, separate strands of legality - international law in the form of the Hungary-China BRI MOU, international G2G commercial law and EU law - started off as separate, with actors even in denial of their entanglement, and ended up in a state that may be called 'interdependent accommodation'. At least for now, EU law and institutions have been placated, and the Belgrade-Budapest project is projected to go ahead.

\subsection{Between Entanglement, State and Empire: Beyond a Conclusion}

In Sections 5.3 and 5.4, we saw that entangled legalities entail both separateness and interdependence of legal systems. In Section 5.1, we saw that legal entanglement need not be the result of chance or accident, but can be a deliberately preferred form of international governance. We can now add to this a final observation: that entangled legalities as a form of governance can be a preference of empire builders and empire bidders (though not exclusively so), and an aggregation of the preferences and attitudes of actors at a variety of levels of action.

In the realm of modern public international law, a similar point has been made with respect to institutional and normative fragmentation by Eyal Benvenisti and the late George Downs: powerful states thrive in fragmented legal environments and encourage them because they divide and rule along functional lines. These environments create high transaction costs for normative integration, and cause ambiguity that deflects accountability despite the existence of power. ${ }^{70}$ In a less positivistic mode, however, sociologists have suggested that we should look at empire as a set of

${ }^{69}$ See 'Talks on Budapest-Belgrade Rail Financing to be Accelerated', Budapest Business Journal (24 September 2019), https://bbj.hu/economy/talks-on-budapest-belgrade-railfinancing-to-be-accelerated_171667.

70 E. Benvenisti and G. W. Downs, 'The Empire's New Clothes: Political Economy and the Fragmentation of International Law' (2010) 60 Stanford Law Review 595-631. 
slow-moving, temporally based, entrenched, yet also changing political formations that need to be studied to understand how they change, adapt and move on to maintain themselves, partly through reproduction and partly through innovation of their institutional structures. ${ }^{71}$ Histories of the British and other European empires, ${ }^{72}$ and of the American 'nonempire, ${ }^{73}$ confirm the relationship between legal pluralism and the creation of imperial domination over extended periods of time. It is no coincidence that Queen Elizabeth included the statement that 'Rome was not built in a day', albeit in different circumstances, in an address at the University of Cambridge in $1564 .{ }^{74}$ No empire, new or old, is so built.

This 'set of slow moving [...] political formations' would seem to inevitably lead to 'entangled legalities', or in other words, to a set of separate, but enmeshed, legal and governance constructs. Although these constructs may seem to lack a hierarchy or 'centre', they nevertheless constitute a system of non-national power allocation, however vague it may be, for example globalization as empire, selon Hardt and Negri. ${ }^{75}$ Alternatively, in a more historified manner, empires may be built on entangled legalities as 'transnational organizations that aim[ed] to mobilize the resources available not only within their areas, but outside them as well' that ' $w$ whatever their origins, [...] ow[ed] their existence and their unity to the broad network of connections that they manage[d] to establish, ${ }^{76}$

These understandings of empire are not, of course, without controversy or critique, as fitting to the topic itself. ${ }^{77}$ They are brought out here to accentuate - once again, descriptively but implicitly critically - that BRI, with its attributes and character of entangled legalities, shares similarities with other imperialist projects, representing a shift 'beyond the state' and perhaps postnational or transnational trends, at a time that

${ }^{71}$ K. Barkey, Empire of Difference: The Ottomans in Comparative Perspective (Cambridge University Press, 2008), p. 5.

${ }^{72}$ L. Benton and R. J. Ross (eds), Legal Pluralism and Empires, 1500-1850 (New York University Press, 2013).

73 D. Immerwahr, How to Hide an Empire: A History of the Greater United States (Farrar, Straus and Giroux, 2019).

74 J. Nichols, The Progresses and Public Processions of Queen Elizabeth, Vol. 1 (John Nichols and Son, 1823), p. 176.

75 M. Hardt and A. Negri, Empire (Harvard University Press, 2000).

76 H. Kamen, Empire: How Spain Became a World Power, 1492-1763 (Harper Collins, 2003).

77 F. Cooper, 'Empire Multiplied: A Review Essay' (2004) 46 Comparative Studies in Society and History 247-72. 
seems to be marked by heightened statism, nationalism and perceived disrespect for international law.

All of this is manifested in BRI, which combines both a non-national, ultimately global vision with localized segments that can be recognized and comprehended along national, territorial and object-oriented lines. Pre-national, postnational - perhaps the only way to understand entangled legalities is through the lens of empire: 'a new and all-pervasive system of power, based on networks and amorphous connections, rooted nowhere in particular. ${ }^{78}$ 'Nowhere in particular' is not necessarily a geographical statement. Communism was 'rooted' in Moscow, 'globalization' in Washington; both were empires by this definition, both built upon nationalism and created and encouraged 'entangled legalities' (with separateness) in multiple ways. BRI might be thought of in a similar fashion.

78 Ibid., 248, describing Hardt and Negri. 
